\title{
TRADITIONAL HEALTHCARE AND PATIENT RESPONSE SERVICES IN KARO REGENCY
}

\author{
Sri Agustina Sembiring Keloko, R. Hamdani and Amri Amir \\ Sekolah Pascasarjana, Universitas Sumatera Utara \\ rhamdani@usu.ac.id
}

\begin{abstract}
Keywords: Hattra, Medicinal Plants, Potions, Patients.
Abstract: $\quad$ Local knowledge developed based on experience has been tested for use for centuries and adapted to local culture and environment as well as in Karo Regency. Karo people have long known traditional medicines are diverse, know several types of diseases as well as how to treat them. This knowledge is one of the local wisdom that persists today. This research is qualitative, the determination of informants using Snowball Sampling techniques, data collected through in-depth interviews and observations. Key Informant as many as 17 people from 7 sub-districts. The traditional form of health care in Karo regency is $67 \%$ skill, herb $27 \%$, and combination (skill and herb) 6\%. Moreover, the age which has a small percentage (20-30 years) of 5.58\%, the most significant 51 years and above with a percentage of $70 \%$, how to acquire the most skills is hereditary (empirical) as much as $71 \%$, the most jobs besides Hattra are farmers (59\%) and does not have a permit /STPT of $82 \%$. Of the 40 respondents, $80 \%$ expressed dissatisfaction and $20 \%$ expressed dissatisfaction with hattra's service. The traditional herb by ethnic Karo is known as the "Karo remedy".. Tanaman drugs are often used gagatan harimo, lempuyang, pepper, garlic, shallots, bahing, tinggeren dredge flowers, and small oranges. Karo uses this plant as a raw material for the manufacture of karo oil, param and tawar.
\end{abstract}

\section{INTRODUCTION}

The way traditional medicine and traditional medicine have been recognized since time immemorial and until now has been utilized by society with constantly increasing censoring. The utilization of traditional medicine can be as an alternative treatment both done by families and the community, as well as through formal health services such as health centers and hospitals when proven benefits andsafety.

Traditional medicine or so-called Etnomedicine is a pattern of beliefs and practices (cultures) related to the way diseases are healing that are the result of the experience and development of indigenous cultures that do not come from the conceptual framework of modern medicine or the so-called non western medical system. (Foster and Anderson 2015).

The role of traditional medicine that has been going on for generations from the past now seems to get attention and development from the Government, seen from various policies such as the publication of the Decree of the Minister of Health Number: 1076 Year 2003 on the implementation of Traditional
Medicine, Government Regulation No. 103/2014 concerning Traditional Health Services and Decree of the Minister of Health No. 61 of 2016 concerning Empirical Traditional Health, in which traditional medical actors were previously called "shamans", but after the publication of the above policies called "Traditional Healers" (Battra) was later revised as "Traditional Healer" (Hattra).

Traditional health services as part of health efforts that according to cultural history and reality to date are found in Indonesia alongside conventional health services are directed to create a healthy, independent and just society. Generally traditional health care providers claim to have clinical evidence of healing in treating diseases, There are several types of Traditional Health services including: Empirical Traditional Health Services, Complementary Traditional Health Services and Traditional Health Services Integration, In providing services, empirical traditional health services are carried out using skills and/or potions, techniques used in skills can be manual engineering, energy therapy and thought therapy (Government Regulation No. 103 of 2014). According to Basic Health Research 2013 the reason households utilize traditional health services in 
general is to maintain health/fitness, except in traditional health services skills and processed therapies on the grounds of utilization based on tradition or trust.

Herbs are known to pose no threat to human life, and apart from healing, they provide the necessary nutrients for the health and development of the human body. The use of natural ingredients is moreacceptableby the human body than the use of synthetic materials, although they know very well that theefficacy of utilization of natural ingredients tends to be relatively slow (Deviani M, et al. 2011). Now, the ability to return to nature (back tonature) Nasudah is global, characterized by the rise of natural material products both from home and from abroad with various labels and brands. In addition, folk remedies can be obtained, diramu and planted without medical personnel (Wakidi,, 2003).

Many argue it is important to nurture traditional healers in order to continue the continuity of their expertise so that they are no longer known or known to benefit because there is no information from traditional healers who have passed away and the absence of knowledge transfers to the next generation due to a lack of interest in traditional medicine or fear of knowledge transfer to ensure protection of the practice of the hattra. It is a fact acknowledged in the literature that traditional medical practitioners tend to hide the identity, usability, manner of brewing and crop measure used for different diseases because patients can treat themselves so that traditional healing practices are unsustainable and society suffers great harm because when practitioners (traditional healers) die, they go along with a wealth of knowledge (Karim, A, et al 2012). This is in line with the Government statement through the Ministry of Health of the Republic of Indonesia which states the traditional medicine in question needs to be fostered and supervised in order to be directed in order to be a treatment and or other means of treatment that can be accounted for its benefits and safety and needs to be developed to realize the optimal level of health for mayarakat (Kepmenkes 1076 Year 2003).

In the search for community medicine regardless of culture in daily life, the supply of traditional ingredients medicine as the national cultural heritage of the Indonesian nation is perceived to play an increasing role in the pattern of people's lives both in terms of health and the economy of the community is increasingly built using natural ingredients medicine and increasingly believe in its benefits for health (Zalbawi, S 2002). This is because each culture has developed a health system that supports the reciprocal relationship that prevails in people's view of life. The rise of Traditional Healer practices in the field of Skills and Potions in North Sumatra, especially in Karo regency which has 17 sub-districts with a population of approximately 389,591 people, famous for its Traditional Healers (Hattra)has typical skills / herbs (Local Wisdom). Traditional medicine that still belongs to and is believed by karo people to this day, among others: the treatment of fractures using yellow (param), tawar, minyak alun or sequential oil, sembur also there oukup or steam bath, from the description above then the author is interested in carrying out research in Karo district.

\section{RESEARCH METHODS}

Research conducted is Qualitative Descriptive is a research procedure that produces written and oral data from people and behaviors that can be observed from a natural environment (Moleong 1991:3), data obtainedfrom the results of interviews (Indepth Inteview) as well asthe filling of questionnaires presented in the form of narration, images and tables.. The observation site was conducted in Karo Regency of North SumatraProvince. Research Time is conducted from December 2016 - February 2017.

The sampling techniques in this study aresnowball sampling method and Purposive Sampling for Hattra, determination for patients is by Census Sampling method. The data in this study consists of primary data and secondary data. Primary data is observations, questionnaires, interviews. Interviews are conducted by way of discussion with Traditional Healers, patients as well as stake holders in Karo Regency to know the problems and obstacles faced in the services provided by traditional healers in Karo Regency. Research objects, among others: People in Karo Regency, especially Traditional Healers and their patients.

Research objects, among others: People in Karo Regency, especially Traditional Healers and theirpatients. The second instrument is used to respondents consisting of Patients (Clients) of traditional healers through questionnaire filling.

\section{RESULTS AND DISCUSSIONS}

Karo people have long known traditional medicines that are diverse. This shows that karo people know several types of diseases as well as ways of treating them. This knowledge is said to be one of 
the local wisdom that still persiststoday. Out of the 17 (seventeen)sub-districts in KaroRegency, almost every sub-district has traditional healers, based on data obtained from karo district health office and how to take sampling done in snowball, hattra data (Traditional Healer) obtained as many as 101 people from 17 sub-districts.

Based on the Decree of the Minister of Health No.61 of 2016 on Empirical Health Services, the way of treatment and traditional services is divided into 3 (three) parts: Skills, Potions and Combinations. Then, based on data obtained from karo district health office and questionnaire, it is known from hattra number as many as 101 people obtained skill treatment (49\%), herb (42\%) and combination (10\%) i.e. Hattra skilled skills and potions..

Hattra who is included in the skill service in this respondent include Shaman Fracture, Reflection, Kusuk Urat and Kebatinan. While those included in the herb service include Hattra which provides children's sawan herb service, kidney stone herb and oukup, in addition to the rise of Hattra herb makers such as yellow, fresh and sequential oil are drugs that have high demand because it is considered medicines that are considered "mandatory medicines" owned by karo people. The last grouped into combination services in this respondent was a combination of massage and the use of potions such as oil, fresh, and param, namely Hattra Kem-kem which practices in Pajak Singa district kabanjahe every Monday.

Then, based on data in the field from 101 Hattra, hatrra's highest age frequency is $>60$ years by $39 \%$, while the age of $20-30$ years is at least $1 \%$, yang which is due to the effect of globalization with the influx of modern technology causing the mindset of the younger generation to view the modern future away from traditional things. In addition, hattra's lack of motivation is now more likely to advise his children to work in offices such as bank employees, civil servants, doctors, legal experts and so on who are considered more prestigious and guarantee their children's future.

As for the key informants in this study as many as 17 people, with some characteristics. The characteristic of the key informant based on age obtained data is the youngest key informant is $\mathrm{S}$. Sinuhaji (30 years) domiciled in Tiga Panah, the type of skill he has that is Shaman Patah, in addition can also treat sprains or sprains. The oldest key informant is Hattra Dukun Patah Pergendangen (92 years old) who has settled in Simpang Pergendangen village, named H.M.Tarigan who is the 2nd generation of Shaman Patah Pergendangen who started his skills since the age of 17 , has opened a practice in Medan that is currently continued by anaknya.

Then, the characteristics of key informants based on gender, obtained data that the percentage of Hattra Men more than girls, namely $59 \%$ of men and $41 \%$ of women due to the influence of karo culture that prioritizes the heir son in both the property and the derived science, the emergence of hattra heirs according to the results of the study because there are no more male heirs (deceased), no interest in boys towards traditional medicine and are single children..

Characteristics of key informants based on the way of service, found data that the way of service Skills as much as $67 \%$, Potion $27 \%$ and Combination as much as $6 \%$, example Hattra with combination service in respondents is Kem-kem. Then, the characteristics of key informants based on how to obtain expertise obtained data that is the most through hereditary, obtained from often seeing parents provide services,collect potions, and be briefed and knowledge about massage, recognize plants that serve as medicinal plants to be made as potions, in addition the offspring given knowledge are also considered talented to continue their expertise.

The characteristic of the key informant based on other work (other than as Hattra) obtained data namely hattra's other work is Farmers as many as 10 people $(59 \%)$, accordingt o its geography which has fertile soil and cool air. Hattra who does not have another job as many as 4 people (24\%), some in addition to being hattra self-employed generally trade and have a business as many as 2 people $(12 \%)$, as in Hattra B.Sinuhaji peracik potion Oukup, in addition to opening oukup practice in Tiga Panah also opened practices in Berastagi and Bandar Baru. Then, the characteristics of the key informant based on the license / STPT from the Karo District Health Office, obtained data that is total percentage hattra who has a license / Registered Letter of Traditional Healer (STPT)very little yakni $18 \%$, as much as $82 \%$ do not have STPT, sub-district that is far from the District Health Office does not have information about the creation of such permits.. Most traditional healers assume permit issuance is difficult and the presumption that paramedics do not recommend traditional Karo concoctions because they do not have the right dosage, are less hygienic and less attractive packaging such as herbal remedies that have been developing lately.

Furthermore, based on research that has been done in karo soil, found 78 types of medicinal plants based on the results of the author's interview with Hattra. As for the whole medicinal plant is all kinds of medicinal plants live wildly in the forest as well as in 
cultivation outside the area by karo people, such as shrubs, shrubs, and trees. Of the 17 Key Informants interviewed, only 1 Hattraused a mixture of animal bodies, namely for the manufacture of bargaining (bargaining to increase malestamina). Fresh material is a wide variety of medicinal plants from the forest combined with dog skotum. However, hattra's most widely used type of medicinal plant coincides with traditional healing services based on local culture namely tiger gagatan, lempuyang, pepper, garlic, shallots, bahing, tinggeren dredge flowers, and small oranges. This plant is used by Karo as raw material for the manufacture of Karo, param and tawar oil.

In this study, 40 respondents who came to Hattra respondents in 7 sub-districts wereinterviewed. The characteristics of patients based on education are obtained data which is the highest percentage is $32.5 \%$ of patients who come to Hattra high school educated from Karo district, Simalungun and Pematang Siantar, there is no education as much as $25 \%$ because infant/toddler patients who take the decision to come to Hattra majority of mothers who are educated are generally high school, while patients who are educated in junior high school $17.5 \%$ who come from villages in Karo and Sarjana districts each as many as $17.5 \%$ ofpatients who are from Medan and surroundingareas.

Patient characteristics based on employment obtained data that is the highest percentage of patient jobs are self-employed (25\%) farmers (25\%), followed by no employment $(22.5 \%)$ namely infant/toddler patients who make the most use of Hattra Kem-kem and broken shaman Barong Kersap. Student patients $(15 \%)$ most of them used Hattra's services to break down due to traffic accidents resulting in broken, sprained and bruised. Each (5\%) have jobs as civil servants and private employees who utilize the services of Hattra shaman broken and Kem-kem. While as many as $(2.5 \%)$ is a retired civil servant who has a stroke who utilizes Hattra reflectionservices.

Characteristics of patients based on insurance owner obtained data that generally patients who come to Hattra do not have health insurance (BPJS) as much as $75 \%$ and who have BPJS as much as $25 \%$ because patients work as civil servants and private employees.. The cost of medical or conventional medicine is one of the reasons people turn to traditional medicine, they estimate it can still cope with the cost when treating to Hattra, this is one of the reasons most patient respondents do not have BPJS..

The reason patients come to Hattra is obtained data is because if they get traditional treatment quickly cured or more effective as much as $65 \%$, followed do not want surgery as much as $17.5 \%$ expressed by the patient fractures, generally theyhave a case of traffic accident so that severe and minor fracture injuries, by doctors are recommended for surgery and pen pairs, but they prefer to get the treatment of shaman fractures because they believe in hattra's ability to heal even in a longer time than medical treatment (conventional).

Related to patients getting information about Hattra, obtained data that is the most information source is from friends (30\%) from neighbors $(25 \%)$ and siblings (25\%) then parents $(12.5 \%)$ and from inlaws $(7.5 \%)$. Di Karo district there are some Hattra who promote themselves only over the radio, but Hattra who was the respondent to this study stated not promoting his expertise, according to their own people who know their expertise..

Then in terms of cost range, data is obtained that is known to patients who state the cost of treatment to Hattra is affordable $(92.5 \%)$ according to the results of the interview when compared to treating a doctor or conventional treatment will be more expensive than they spend, while those who declare it unaffordable $(7.5 \%)$ is a fractured patient with severe injuries with long inpatient care (hampir 4 months).). Some Hattra do not charge rates at all in treating people. However, it is customary for patients to always give money or other gifts (rice, sarongs, clothing, etc.) to Hattra as a form of reciprocity because the shaman cures his illness. Therefore, the patient also understands this condition and understands, so that the patient always gives money to Hattra every time it is treated.

In terms of the distance of time a patient visits to Hattra, the most visit data is obtained once a week $(40 \%)$ in infant/infant patients who are treating hattra combination and shaman fractures, visits once a month (25\%) for patients kusuk fitness and control of broken shaman patients, visits 1-3 days (20\%) for patients with inpatient fractures or severe injuries, the last visit was 2 weeks (15\%) for fracture patients and potions. In terms of the background of the patient's tribe, obtained data that is basedon its geographicallocation, the tribe that utilizes hattra services in Karo regency is karo (72\%), followed by Batak (12\%) from Simalungun and Pematang Siantar, Javanese (10\%), Mandailing (3\%) and Malay (3\%).

Then in terms of the level of recovery and satisfaction of patients, obtained data that patients who are satisfied with the service because there are advances in health also believe in the efficacy of the herb given by Hattra and cured and the cost that tends to be cheaper than medical treatment (Conventional) is $(80 \%)$, while patients who are dissatisfied as much 
as $(20 \%)$ for reasons still doubting the cleanliness or hygiene of the herb obtained, according to the patient there is still finding small animals or sand from a solid -shaped herb (yellow), as well as the way hattra that dryes the herb in the yard of the house on the side of the road, another reason hattra access is far from the residence for patients who come from Medan..

As it is known the Government has regulated traditional health services in the Law of the Republic of Indonesia No.36 of 2009 concerning Health, Government Regulation No.103 of 2014 and the last one was only launched by the minister of health, namely the Decree of the Minister of Health No.61 of 2016 on Empirical Traditional Health Services, in which the Ministry of Health clearly regulates the implementation of Empirical health services (hereditary) which is widely found in Karodistrict, the local authority of provincial and district governments, includingthe procedure of issuing permits that can be used as a reference for karo districtgovernment. Thus, the regulations governing the coaching and supervision of traditional health services conducted by Hattra still follow the regulations issued by the government regulations and the minister's decisions. Thisis due to the absence of Pergub from the provincial government or Perda from the local government of Karo Regency.

\section{REFERENCES}

Foster, G. dan Anderson G. 2015. Antropologi Kesehatan, Penerjemah; Priyanti PS, Terjemahan dari : Medical Antropology, Penerbit Universitas Indonesia.

Karim, A. dkk. 2012. Ethnobotanical Assesment of Herbal plants in South Western Nigeria. Academik Research International. Vol.2 No.3 May, ISSN-L-2223-9553.

[Kemenkes RI] Kementerian Kesehatan. 2003. Kepmenkes No 1076/Menkes/SK/VII/2003 tentang Penyelenggaraan Pengobatan Tradisional. Jakarta.

Kemenkes RI. 2014. Peraturan Pemerintah No 103/ 2014 tentang Pelayanan Kesehatan Tradisional. Jakarta.

Kemenkes RI. 2014. Peraturan Pemerintah No 103/ 2014 tentang Pelayanan Kesehatan Tradisional. Jakarta.

Kemenkes RI. 2016. Peraturan Menteri kesehatan Nomor 61 Tahun 2016 Tentang Pelayanan Kesehatan Tradisional Empiris. Jakarta.

Wakidi. 2003. Pemasyarakatan tanaman obat keluarga "TOGa" untuk mendukung penggunaan sendiri "self medication". Bagian Farmasi Kedokteran Fakultas Kedokteran Universitas Sumatera Utara. Medan Hal: 3. edisi 2003.

Diunduh dari http:/antiterasi.multiply.com/journal/item/23.

Zalbawi, S. 2002. Pola Pemanfaatan Pengobatan Tradisional Oleh Pasien Rematik. Badan Penelitian dan Pengembangan Kesehatan. Februari Vol.1 No.1. 